\title{
Job Satisfaction of Medical Teachers in Bangladesh : Who Are More Satisfied?
}

\author{
Rawshan Ara Khanam ${ }^{1}$, Humayun Kabir Talukder ${ }^{2}$, Tahmina Nargis ${ }^{3}$, Afrin Rubaiyat ${ }^{4}$
}

\begin{abstract}
Introduction: Job satisfaction is a complex function of a number of variables related to the teachers demographic characters, the work itself, pay, work responsibilities, variety of tasks, promotional opportunities, and relation with co-workers etc. A person may be satisfied with one or more aspects of his/her job but at the same time may be unhappy with other things related to the job. Teachers job satisfaction is associated with teachers effectiveness which ultimately affects students achievements. Job satisfaction has been variously linked with increased performance and negatively with absenteeism and turn over.

Methodology: It was a cross sectional type of descriptive study, conducted in 10 medical colleges, of these 5 were non government and 5 were public medical colleges for one year (July 2011 to June 2012) with the aim to determine the medical teachers who were more satisfied with their job. Total respondents were 218 teachers selected by convenience sampling ,working in preclinical, para clinical and clinical departments of those medical colleges. Pretested, self-administered , structured, anonymous, using English ,questionnaires with Likert scale was used for data collection . Comparison of satisfaction level between male and female teachers, teachers working in nongovernment and government medical colleges, in central and peripheral medical colleges, senior and junior teachers were done by applying unpaired t test. The level of significance was considered as $<0.05$ and confidence interval was $95 \%$. $41 \%$ teachers were female, $87 \%$ were married and $81 \%$ had post graduate degrees.

Results : Mean age of the respondents were 42 years and they passed 3 years after last promotion. Regarding theme 1-7 there were no significant difference in satisfaction in male and female teachers but in theme 8 (central administration), $p$ value of two tailed unpaired t test was .009. It means that female teachers were less satisfied than their male counter part regarding central administration. Among the 8 themes, central level teachers were more satisfied $(\mathrm{p}<.009)$ in relation with others. Teachers working in peripheral medical colleges were significantly $(p<.001)$ more satisfied with facilities other than the salary. There were significant satisfaction among the teachers of private medical colleges in all the themes except clinical teachers satisfaction. Junior teachers were significantly less satisfied than their seniors in all aspects of their job.

Conclusions :Teachers working in non government sectors were more satisfied than the teachers of government sectors in most of the cases. Male teachers are a bit more satisfied than their female counterpart .Satisfaction level is higher among senior teachers. Job satisfaction of clinical and non clinical teachers were similar except regarding facilities enjoyed other than the salary. Teachers were satisfied with their teaching related items but they were dissatisfied with administration.
\end{abstract}

\section{Key Words:}

\section{Introduction}

Medical profession has witnessed tremendous change in the last four decades. With the advent of other attractive careers there is a decline in interest in medical career. Main reasons for the change were general dissatisfaction, lifestyle incompatibility, training and practice, teaching and other problems in medical career ${ }^{1}$. This low job satisfaction may be due to increasing stagnation, undesired political and administrative interference, litigation, poor working

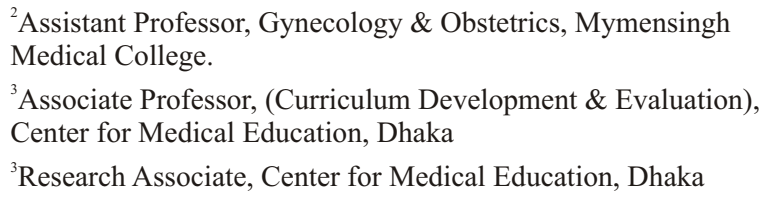

${ }^{2}$ Address of correspondence: Dr. Rawshan Ara Khanam, Assistant Professor, Gynecology \& Obstetrics, Mymensingh Medical College. conditions in teaching hospitals and poor salary. As compared to public set up private set up offers better working conditions with better pay. Doctors level of job satisfaction and changes in satisfaction varies greatly among regions and according to organizational models of health care ${ }^{2}$.

Job satisfaction is a complex function of a number of variables related to the teachers demographic characters, the work itself, pay, work responsibilities, variety of tasks, promotional opportunities, and relation with co-workers etc.

A person may be satisfied with one or more aspects of his/her job but at the same time may be unhappy with other things related to the job ${ }^{3}$.Job stress is a recognized problem in health care professionals including medical teachers which leads to higher degrees psychological morbidity ${ }^{4}$. For medical teachers intrinsic satisfaction can came from class room activities, daily interaction with students, students learning from their teaching. Professional autonomy enhances the attractiveness of teaching profession and

Bangladesh Journal of Medical Education 2011;2(2):12-17. (C) 2011 Ara et al., publisher and licensee Association of Medical Education. This is an Open Access article which permits unrestricted non-commercial use, provided the original work is properly cited. 
improves the class room performance. Intrinsic factors plays role for motivating peoples for teaching profession. Most of the teachers enjoys teaching and wants to work with the young peoples. Very few teachers enter in to teaching for external rewards like- salary, prestige or benefits. However internal factors motivate peoples to become teacher but external factors influences their satisfaction $^{5}$. A high quality teaching staff is the corner stone of a successful educational system. Daily interaction between teachers and students is at the centre of the educational process. For developing and retaining high quality faculty most important factor is job satisfaction. It is not only the job satisfaction but with career in general that is important. Teachers job satisfaction is associated with teachers effectiveness which ultimately affects students achievements . Job satisfaction has been variously linked with increased performance and negatively with absenteeism and turn over. In teaching institute this may be translated into his academic out put, may influence the morale and attitudes ${ }^{6}$.

The quality education is a positively directed action, for which teachers are to be endeavor with satisfaction towards a job and the need of possessing the quality. This is the right time to focus the significance of teacher job satisfaction ${ }^{7}$ in relation to medical teachers.

\section{Methodology}

It was a cross sectional type of descriptive study, conducted in 10 medical colleges, of these 5 were non government and 5 were public medical colleges for one year (July 2011 to June 2012). Total respondents were 218 teachers selected by convenience sampling, working in preclinical, para clinical and clinical departments of those medical colleges .

Pretested, self-administered, structured, anonymous, using English, questionnaires with Likert scale was used for data collection. This approach produced an initial pool of 47 items. Among these items, 8 items were the variables measuring the general characters. Other 39 items were included in structured questionnaires. Each of the 39 items had 5- point Likert response categories from highly satisfied $=5$ to highly dissatisfied $=1$ score. In Likert scale score 3 is for undecided. Score more than 3 was perceived as satisfied and less than 3 was perceived as dissatisfied.

All the collected data has been checked manually. Data editing, entry, processing and analysis has been done by using 15 version of SPSS. For clear understanding of the result, the information were grouped into three facets- A,B and C. Related items were grouped in to themes and related themes were grouped under individual facet.

Facet- A. Socio-demographic characters of the respondents, which contains 8 characteristics including-age, gender, designation and various other items measuring general affect . Facet - B. Job satisfaction related to teaching was again subdivided into 5 themes, which includes 24 items . The themes were related to relation with others, teaching related responsibilities, teaching environment, work related satisfaction, and facilities enjoyed other than salary. FacetC. Job satisfaction related to administration, which was subdivided into 3 themes - which has total 15 items, related to local and central administrations and clinical teacher's satisfaction.

Comparison of satisfaction level between male and female teachers, teachers working in nongovernment and government medical colleges, in central and peripheral medical colleges, senior and junior teachers were done by applying unpaired t test. The level of significance was considered as $<0.05$ and confidence interval was $95 \%$.

There was no ethical problem because all the information has been collected anonymously with prior permission of the authority and the participants has given their opinion voluntarily. Researcher maintained confidentiality in all cases.

\section{Results}

Table 1: Distribution of the respondents by their demographic characteristics and service related information $(\mathrm{n}=218)$

\begin{tabular}{|l|l|}
\hline \multicolumn{1}{|c|}{ Characters } & No. ( \%) \\
\hline Male & $128(59 \%)$ \\
\hline Female & $90(41 \%)$ \\
\hline Married & $190(87 \%)$ \\
\hline Unmarried & $28(13 \%)$ \\
\hline Post graduate & $176(81 \%)$ \\
\hline Graduate & $37(17 \%)$ \\
\hline Age ( mean age) & 42.37 years \\
\hline Mean length of service(years) & 13.18 years \\
\hline $\begin{array}{l}\text { Mean period passed after last } \\
\text { promotion (years) }\end{array}$ & 3.08 years \\
\hline
\end{tabular}

Table 1: showing that, $41 \%$ teachers were female , $87 \%$ were married and $81 \%$ had post graduate degrees. Mean age of the respondents were 42 years and they passed 3 years after last promotion.

Table 2 : Comparison of job satisfaction between male and female teachers according to themes. 


\begin{tabular}{|c|c|c|c|c|c|}
\hline Theme & Gender & $\mathbf{N}$ & Mean & $\mathbf{t}$ & Pvalue \\
\hline \multirow[t]{2}{*}{ Relation with others } & Male & 122 & 16.3115 & \multirow[t]{2}{*}{1.183} & \multirow[t]{2}{*}{.238} \\
\hline & Female & 80 & 15.8750 & & \\
\hline \multirow[t]{2}{*}{ Teaching responsibilities } & Male & 107 & 20.9907 & \multirow[t]{2}{*}{.156} & \multirow[t]{2}{*}{.876} \\
\hline & Female & 71 & 21.1408 & & \\
\hline \multirow[t]{2}{*}{ Teaching environment } & Male & 124 & 13.4597 & \multirow[t]{2}{*}{1.003} & \multirow[t]{2}{*}{.317} \\
\hline & Female & 82 & 13.0244 & & \\
\hline \multirow[t]{2}{*}{ Satisfaction with current work } & Male & 120 & 11.9750 & \multirow[t]{2}{*}{.373} & \multirow[t]{2}{*}{.710} \\
\hline & Female & 81 & 11.7901 & & \\
\hline \multirow[t]{2}{*}{ Facilities enjoyed } & Male & 91 & 13.1758 & \multirow[t]{2}{*}{1.609} & \multirow[t]{2}{*}{.110} \\
\hline & Female & 56 & 11.6964 & & \\
\hline \multirow[t]{2}{*}{ Local administration } & Male & 119 & 14.2521 & \multirow[t]{2}{*}{1.477} & \multirow[t]{2}{*}{.141} \\
\hline & Female & 73 & 13.3151 & & \\
\hline \multirow[t]{2}{*}{ Central administration } & Male & 100 & 18.7900 & \multirow[t]{2}{*}{2.662} & \multirow[t]{2}{*}{.009} \\
\hline & Female & 70 & 16.7000 & & \\
\hline \multirow[t]{2}{*}{ Clinical teachers satisfaction } & Male & 77 & 14.4156 & \multirow[t]{2}{*}{.808} & \multirow[t]{2}{*}{.420} \\
\hline & Female & 54 & 14.0185 & & \\
\hline
\end{tabular}

Regarding theme 1-7 there were no significant difference in satisfaction in male and female teachers but in theme 8 (central administration), $\mathrm{p}$ value of two tailed unpaired $\mathbf{t}$ test was .009. It means that female teachers were less satisfied than their male counter part regarding central administration other wise they were equally satisfied.

Table 3 : Comparison of level of job satisfaction based on location of Institute

\begin{tabular}{|c|c|c|c|c|c|}
\hline Theme & Gender & $\mathbf{N}$ & Mean & $\mathbf{t}$ & P value \\
\hline \multirow[t]{2}{*}{ Relation with others } & central & 1 & 16.6986 & \multirow[t]{2}{*}{2.630} & \multirow[t]{2}{*}{.009} \\
\hline & peripheral & 129 & 15.8217 & & \\
\hline \multirow[t]{2}{*}{ Teaching responsibilities } & central & 66 & 21.4697 & \multirow[t]{2}{*}{.684} & \multirow[t]{2}{*}{.495} \\
\hline & peripheral & 112 & 20.8036 & & \\
\hline \multirow[t]{2}{*}{ Teaching environment } & central & 76 & 13.3026 & \multirow[t]{2}{*}{.058} & \multirow[t]{2}{*}{.954} \\
\hline & peripheral & 130 & 13.2769 & & \\
\hline \multirow[t]{2}{*}{ Satisfaction with current work } & central & 72 & 11.9167 & \multirow[t]{2}{*}{.050} & \multirow[t]{2}{*}{.960} \\
\hline & peripheral & 129 & 11.8915 & & \\
\hline \multirow[t]{2}{*}{ Facilities enjoyed } & central & 41 & 10.4878 & \multirow[t]{2}{*}{-3.354} & \multirow[t]{2}{*}{.001} \\
\hline & peripheral & 106 & 13.4340 & & \\
\hline \multirow[t]{2}{*}{ Local administration } & central & 74 & 13.7027 & \multirow[t]{2}{*}{-.494} & \multirow[t]{2}{*}{.622} \\
\hline & peripheral & 118 & 14.0169 & & \\
\hline \multirow[t]{2}{*}{ Central administration } & central & 68 & 18.2500 & \multirow[t]{2}{*}{695} & \multirow[t]{2}{*}{.488} \\
\hline & peripheral & 102 & 17.7157 & & \\
\hline \multirow[t]{2}{*}{ Clinical teachers satisfaction } & central & 50 & 14.6600 & \multirow[t]{2}{*}{1.332} & \multirow[t]{2}{*}{.185} \\
\hline & peripheral & 81 & 14.0000 & & \\
\hline
\end{tabular}

Among the 8 themes, central level teachers were more satisfied $(\mathrm{p}<.009)$ in relation with others. Teachers working in peripheral medical colleges were significantly $(\mathrm{p}<.001)$ more satisfied with facilities other than the salary. 
Table 4: Comparison of level of job satisfaction of teachers according to the type of medical colleges

\begin{tabular}{|c|c|c|c|c|c|}
\hline Theme & Type of teacher & $\mathbf{N}$ & Mean & $\mathbf{t}$ & Pvalue \\
\hline \multirow[t]{2}{*}{ Relation with others } & Government & 121 & 15.4215 & \multirow[t]{2}{*}{-5.153} & \multirow[t]{2}{*}{.000} \\
\hline & Non Govt. & 81 & 17.2099 & & \\
\hline \multirow[t]{2}{*}{ Teaching responsibilities } & Government & 102 & 18.5784 & \multirow[t]{2}{*}{-7.000} & \multirow[t]{2}{*}{.000} \\
\hline & Non Govt. & 76 & 24.3684 & & \\
\hline \multirow[t]{2}{*}{ Teaching environment } & Government & 123 & 12.4634 & \multirow[t]{2}{*}{-5.083} & \multirow[t]{2}{*}{.000} \\
\hline & Non Govt. & 83 & 14.5060 & & \\
\hline \multirow[t]{2}{*}{ Satisfaction with current work } & Government & 121 & 10.9339 & \multirow[t]{2}{*}{-5.423} & \multirow[t]{2}{*}{.000} \\
\hline & Non Govt. & 80 & 13.3625 & & \\
\hline \multirow[t]{2}{*}{ Facilities enjoyed } & Government & 92 & 10.1729 & \multirow[t]{2}{*}{-8.602} & \multirow[t]{2}{*}{.000} \\
\hline & Non Govt. & 55 & 16.6909 & & \\
\hline \multirow[t]{2}{*}{ Local administration } & Government & 113 & 12.2655 & \multirow[t]{2}{*}{-7.079} & \multirow[t]{2}{*}{.000} \\
\hline & Non Govt. & 79 & 16.2278 & & \\
\hline \multirow[t]{2}{*}{ Central administration } & Government & 119 & 17.4370 & \multirow[t]{2}{*}{-1.710} & \multirow[t]{2}{*}{.091} \\
\hline & Non Govt. & 51 & 19.0784 & & \\
\hline \multirow[t]{2}{*}{ Clinical teachers satisfaction } & Government & 88 & 14.2386 & \multirow[t]{2}{*}{$\begin{array}{l}.078 \\
\end{array}$} & \multirow[t]{2}{*}{.938} \\
\hline & Non Govt. & 43 & 14.2791 & & \\
\hline
\end{tabular}

There were significant satisfaction among the teachers of private medical colleges in all the themes except clinical teachers satisfaction. Clinical teachers were equally satisfied in both setting regarding availability of the patients for teaching.

Table 5: Comparison of job satisfaction between junior and senior teachers

\begin{tabular}{|c|c|c|c|c|c|}
\hline Theme & Type of teacher & $\mathbf{N}$ & Mean & $t$ & P value \\
\hline \multirow[t]{2}{*}{ Relation with others } & Junior & 66 & 16.2424 & \multirow[t]{2}{*}{.400} & \multirow[t]{2}{*}{.690} \\
\hline & Senior & 136 & 16.0882 & & \\
\hline \multirow[t]{2}{*}{ Teaching responsibilities } & Junior & 56 & 19.8393 & \multirow[t]{2}{*}{-1.756} & \multirow[t]{2}{*}{.081} \\
\hline & Senior & 122 & 21.6066 & & \\
\hline \multirow[t]{2}{*}{ Teaching environment } & Junior & 67 & 13.3453 & \multirow[t]{2}{*}{-.399} & \multirow[t]{2}{*}{.690} \\
\hline & Senior & 139 & 10.9385 & & \\
\hline \multirow[t]{2}{*}{ Satisfaction with current work } & Junior & 65 & 12.3603 & \multirow[t]{2}{*}{-2.786} & \multirow[t]{2}{*}{.006} \\
\hline & Senior & 136 & 10.9000 & & \\
\hline \multirow[t]{2}{*}{ Facilitiesenjoyed } & Junior & 40 & 13.2523 & \multirow[t]{2}{*}{-2.368} & \multirow[t]{2}{*}{.019} \\
\hline & Senior & 107 & 12.6000 & & \\
\hline \multirow[t]{2}{*}{ Local administration } & Junior & 62 & 14.4923 & \multirow[t]{2}{*}{-2.848} & \multirow[t]{2}{*}{.005} \\
\hline & Senior & 130 & 16.7500 & & \\
\hline \multirow[t]{2}{*}{ Central administration } & Junior & 60 & 16.4370 & \multirow[t]{2}{*}{-2.448} & \multirow[t]{2}{*}{.016} \\
\hline & Senior & 110 & 18.5727 & & \\
\hline \multirow[t]{2}{*}{ Clinical teachers satisfaction } & Junior & 30 & 14.7426 & \multirow[t]{2}{*}{-3.931} & \multirow[t]{2}{*}{.000} \\
\hline & Senior & 101 & 12.6452 & & \\
\hline
\end{tabular}

Junior teachers were significantly less satisfied than their seniors in all aspects of their job.

Bangladesh Journal of Medical Education 2011;2(2):12-17. 
Table 6: Comparison of job satisfaction between clinical and non clinical teachers

\begin{tabular}{|c|c|c|c|c|c|}
\hline Theme & Type of teacher & $\mathbf{N}$ & Mean & $\mathbf{t}$ & P value \\
\hline \multirow[t]{2}{*}{ Relation with others } & clinical teacher & 139 & 16.0504 & \multirow[t]{2}{*}{-.827} & \multirow[t]{2}{*}{.409} \\
\hline & nonclinical teacher & 63 & 16.3333 & & \\
\hline \multirow[t]{2}{*}{ Teaching responsibilities } & clinical teacher & 121 & & \multirow[t]{2}{*}{-.142} & \multirow[t]{2}{*}{.887} \\
\hline & nonclinical teacher & 57 & 21.1404 & & \\
\hline \multirow[t]{2}{*}{ Teaching environment } & clinical teacher & 144 & 13.3681 & \multirow[t]{2}{*}{.585} & \multirow[t]{2}{*}{.559} \\
\hline & nonclinical teacher & 62 & 13.0062 & & \\
\hline \multirow[t]{2}{*}{ Satisfaction with current work } & clinical teacher & 140 & 11.7714 & \multirow[t]{2}{*}{-.828} & \multirow[t]{2}{*}{.410} \\
\hline & nonclinical teacher & 61 & 12.1967 & & \\
\hline \multirow[t]{2}{*}{ Facilities enjoyed } & clinical teacher & 104 & 13.4038 & \multirow[t]{2}{*}{2.806} & \multirow[t]{2}{*}{.005} \\
\hline & nonclinical teacher & 43 & 10.6977 & & \\
\hline \multirow[t]{2}{*}{ Local administration } & clinical teacher & 134 & 13.9627 & \multirow[t]{2}{*}{.328} & \multirow[t]{2}{*}{.743} \\
\hline & nonclinical teacher & 58 & 13.7414 & & \\
\hline \multirow[t]{2}{*}{ Central administration } & clinical teacher & 116 & 18.4483 & \multirow[t]{2}{*}{1.949} & \multirow[t]{2}{*}{.052} \\
\hline & nonclinical teacher & 54 & 16.8148 & & \\
\hline
\end{tabular}

There was no significant differences in themes except the facilities enjoyed other than salary . Regarding this theme clinical teachers were more satisfied than the non clinical teachers.

\section{Discussion}

'Any combination of psychological, physiological, and environmental circumstances that cause a person truthfully to say : I am happy with my job 'is job satisfaction defined by Holger et al(2007)8. Mean age of the teachers in this study was 42 years which is the active work force like the study done in Nigeria by Charles et al(2010)9 which was 42.8 years and 30-39 years study done on Kuwait by Ibrahim ,Manal and Huda 10. In a study in Kuwait revealed that, significantly higher the age and number of years working, the higher the job satisfaction. No significant difference in satisfaction for gender, specialty and marital status. "In our culture, males are in majority among any working group, interaction and relationship .Males have more autonomy and freedom than their female counter part, so more job satisfaction" is the situation in Pakistan (Khuwaja et al 2002). In present study level of satisfaction was more or less similar among male and female teachers except regarding central administration. Female teachers were equally satisfied with their overall careers and interpersonal relationship but $60 \%$ more likely than the men to report burn out11. Study done by Fiona et al (2007)12 also showed that female associate specialist in Scotland were less satisfied with all aspect of their job. Janus et al (2008)13 showed in a study that, general life satisfaction and age but not gender were positively associated with job satisfaction among doctors in Norway and Germany.

In the present study teachers working in private sectors were more satisfied than the public sectors . Study done by Geeta Kumari (2011) 14 showed that, public sector is not clear about their endeavors, objective are confusing and indefinite in comparison to private sectors. Departments of private sectors work together so does not create any rift between the different departments. So doctors working in private sectors are more satisfied with their job.

According to study done by Donald et al (2002)15 younger physicians were least satisfied and similarly in this study lecturer and demonstrators were least satisfied. Study by Abigail Zuger (2004)16 showed that, levels of satisfaction varies with geographic location. In present study $\mathrm{p}$ value was significant for satisfaction among teachers working in peripheral medical colleges in 'facilities enjoyed other than salary' and' inter personal relationship'.

\section{Conclusion}

Teachers working in nongovernment sectors were more satisfied than the teachers of government sectors in most of the cases. Male teachers are a bit more satisfied than their female counterpart .Satisfaction level is higher among senior teachers. Junior teachers were less satisfied with their jobs . Job satisfaction of clinical and nonclinical teachers were similar except regarding facilities enjoyed other than the salary. In this aspect clinical teachers were more satisfied. Teachers were satisfied with their teaching related items but they were dissatisfied with administration. 


\section{References}

1. Gupta R, Vohra AK, Gupta A Singla SL. A Study of Hostility, Career choice and Job Satisfaction Among Surgeons, MJAFI . 2002; 58:210-13.

2. Nylenna M, Gulbrandsen P, Forde R, Aasland OG. job satisfaction among Norwegian general practitioners, Scandinavian Journal of Primary Health Care. 2005; 23: 198-202.

3. Ghazali SSA, Shah IA, Zaidi SAA, Tahir MH. Job satisfaction among doctors working at teaching hospital of Bahawalpur, Pakistan, J Ayub Med Coll Abbottabad . 2007; 19(3): 42-45.

4. Khuwaja AK, Qureshi R, Andrades M, Fatmi Z, Khuwaja NK . Comparison of job satisfaction and stress among male and female doctors in teaching hospitals of Karachi, 2002, retrieve on 3.7.2012 mail: ali.khuwaja@aku.edu

5. Job satisfaction among America's teachers: effects of workplace conditions, background characteristics and teacher compensation, July 1997, statistical analysis report, Washington D.C.

6. Madan N. Job satisfaction among Doctors in a Tertiary Care Hospital, JK science, 2008 ;10(2): 81-83.

7. Suryanarayana NVS \& Luciana MZ, Teaching competency and teacher job satisfaction among secondary school teachers, 2010. www. teacher learner.com

8. Gorth H, Koster AD, Storz P, Nolting HD, Haussler B . Job Satisfaction among doctors ,DTSCH ARZTEBL. 2007; 104(20):1394-9.

9. Charles O O, Mukaila AS, Bukola OO, Dantonjo EA .Libyan J Med. 2010; 5:102-103. 4629-DOI: 10.4.176/091010 (reativecommons.org)
10. Ibrahim S Al-Eisa, Manal S Al-Mutar, Huda K AlAbduljalil . Job satisfaction of primary health care physiciansat capital health region, Kuwait, Middle East Journal of Family Medicine . 2005; 3(3) :202-203. retrieved on 3.8.2012 from mmutar@doctor.com.

11. Yeasmin A, Abdulghafour, Anwar M, Bo-hamra , Moneera S, Al-Randi, Mohamed I, Kamel, Medhat k, El- Shazly. Burn out syndrome among physicians working in primary health care centers in Kuwait, Alexandria Journal of Medicine . 2011; 47 (4 ): 351357.

12. French F, Ikenwilo D, Scott A. What influences the job satisfaction of staff and associate specialist hospital doctors? , Health Serv Manage Res. 2007; 2 (3):153161.

13. Janus K, Amelung VE, Baker LC, Gaitanides M, Schwartz FW, Rundall TG . Job Satisfaction and Motivation among Physicians in Academic Medical Centers: Insights from a Cross - national Study, Journal of Health Politics, Policy and Law. 2008; 33(6): 113367.

14. Kumari G \& Pandey KM . Job satisfaction in Public and Private Sector : A Comparison, International Journal of Innovation, Management and Technology . 2011; 2(3): $222-22$

15. Donald E, William E, Thomas R, Eric S, Linzer M, Douglas J. Physician job satisfaction, dissatisfaction, and physician turnover, The Journal of Family Practice. 2002; 51(7): $51-6$.

16. Zuger A. Dissatisfaction with medical practice, NEJM. $2004 ; 350: 69-75$. 